\title{
THE CHANGING ROLE OF THE ATOMIC ENERGY GOMMISSION IN ATOMIC POWER DEVELOPMENT
}

\author{
Robert M. Northrop*
}

Peacetime atomic energy is truly a twentieth-century frontier. It has all the promise, the excitement, and the unexpectedness of the frontiers that spurred the imagination in eras past. Among the many uses of the peaceful atom, the generation of electric power from nuclear fission (and perhaps fusion) is probably the most far-reaching and significant. It may well have an utterly fundamental impact on the economic and social well-being of the peoples of the world. In the words of President Eisenhower, ". . . the atom stands ready to become man's obedient, tireless servant, if man will only allow it."1

At the beginning, more than a decade ago, America jumped into the lead in atomic energy development. Nuclear energy leveled two cities in 1945; since then, its destructive power has been vastly refined and often demonstrated, but never unleashed against human beings as it was at Hiroshima and Nagasaki. The achievement of the A-bomb required an incredible expenditure in men and resources and a necessarily exclusive concentration on destruction. At the war's end, peacetime nuclear power generation was little more than an intriguing possibility in the minds of a few scientists, who had been able to give it only limited attention during the big wartime effort. In the decade that has passed since World War II, however, the peacetime atom has slowly gathered the momentum that now promises to carry it on to provide almost unimaginable benefits for the entire world.

In this country, the influence of the United States Atomic Energy Commission, until recently, has blanketed the whole realm of atomic energy. It was a necessary decision in I946 that kept atomic energy under the complete control of the federal government, where it had developed. The atom remained a governmental monopoly, and the AEC, directly responsible for its development and use, has been the overwhelmingly dominant locus of power in this field, together with the unusually influential Joint Committee on Atomic Energy.

Today there is a trend away from this unique domination by the federal government in the civilian phases of atomic energy. There is under way a program to create a true private atomic power industry under policies agreed upon by all branches of the Government and written into the new Atomic Energy Act of $1954{ }^{2}$ This

*A.B. I949, Yale University; M.A. 1955, Columbia University. Michigan Memorial-Phoenix Project Fellow, University of Michigan. Collaborated with the author, Morgan Thomas, on the forthcoming Atomic Energy and Congress.

${ }^{1}$ N.Y. Times, Aug. 9, x955, p. 8, col. 4 .

${ }^{2} 68$ STAT. 921, 42 U.S.C.A. \$\$20II-28I (Supp. 1954). 
has had a substantial impact on the role of the Commission, for so long the exclusive steward of the atom. Government monopoly is giving way to ever more private participation in nuclear power. The Commission is performing new functions and facing new problems as it moves from its old operating role into the period of transition, marked by government-industry cooperative ventures, that will precede the advent of a private atomic power industry.

\section{The Early Reactor Program}

The early exclusive role of the AEC in atomic power development was carried out under the provisions of the original Atomic Energy Act of $1946 .^{3}$ The AEC was an operating agency in charge of a federally owned enterprise. According to the act, only the Government could own both fissionable materials and utilization facilities-reactors and weapons. ${ }^{4}$ Work in atomic energy, therefore, had to be a program of the Government. This is not to say that other groups and individualsespecially scientists and industrial contractors hired by the AEC-had no influence on the program. It simply meant that the Commission was the only means of access to atomic energy. If there was to be atomic power development, it would have to be done through the AEC.

What, in fact, did the AEC do about atomic power? The possibility of producing power through nuclear fission was seen before the close of World War II. From the Manhattan Engineer District, the AEC inherited a rather rudimentary program of research aimed at solving the fundamental technological problems standing in the way of workable atomic power plants. ${ }^{5}$ Dr. Farrington Daniels, of the University of Wisconsin, had made preliminary studies of power "piles," beginning in 1944 at Oak Ridge, and he had demonstrated their theoretical feasibility. Investigations of anticipated problems were carried on subsequently, and in 1946, this research program was divided between the Clinton Laboratories, at Oak Ridge, and the Argonne National Laboratory, near Chicago.

The MED had also awarded two prime contracts for power development. One, to Monsanto Chemical Company, was for development at Oak Ridge of a reactor based on the Daniels findings and on later research. The other contract, to General Electric, provided for research and development work on several different designs. The government-owned Knolls Atomic Power Laboratory, near Schenectady, New York, was established in November I946 to facilitate this program.

Here, then, was a small but going program which the AEC took over from the MED. But even the feasibility of nuclear power was not yet assured. The range of difficult problems to be solved was enormous, and the effort required was a long, difficult, and costly one. Cheap nuclear power seemed hardly on the horizon in I946.

${ }^{3} 60$ STAT. 755,42 U.S.C. $\$ \$ x 80 \mathrm{I}-\mathrm{T} 9$ (x946).

¿ $\$ \$_{4}(\mathrm{c})(\mathrm{I}), 5$ (a)(2), 60 STAT. 759, 760, 42 U.S.C. $\$ \$ 1804$ (c)(r), 1805(a)(2) (1946).

$\checkmark$ The Manhattan Engineer District program is described in a 1946 press release reprinted in Joint Committee on Atomic Energy, Atomic Power and Private Enterprise, 82d Cong., 2d Sess. 174-78 (1952). 
The AEC, when it took over the project, faced the problem which faces any agency: to balance the benefits to be derived from one program against those of other programs upon which the same money and effort might be expended. This question of priorities faced the Commission at once, and the answer was a foregone conclusion. Atomic power in the United States was not immediately necessary, since other sources offered plentiful power for the time being. Broad and energetic weapons and production programs, however, seemed extremely urgent, to say the least. The incoming Commissioners found that these programs were far weaker than had been expected, and the weapons and materials stockpile was surprisingly small. Scientific and technical personnel were leaving the project at the conclusion of the war, just when they were needed to push ahead with weapons development and to solve certain technical difficulties that had arisen-such as those threatening to shut down the plutonium-producing reactors at Hanford. ${ }^{6}$

To concentrate on these primary jobs, the AEC put atomic power development at a low priority. Some attention was given, it is true, to other peacetime uses, such as radioactive isotopes. But isotopes could be easily and quickly produced in the alreadyexisting experimental "piles," and the usefulness to medicine and industry of cheaply produced isotopes was great. Atomic power, on the other hand, was speculative, uncertain, and obviously expensive and difficult. There seemed to be no justification for undertaking such a major effort at that time.

For these reasons, reactor development under the AEC was, for almost two years, a relatively minor program. The Commission, in carrying on the small MED program, did achieve some measure of progress. Some of the results were disappointing, however: Oak Ridge completed its studies of a gas-cooled reactor in late 1947, but the AEC, on the basis of these studies, decided not to proceed with what had turned out to be an unpromising design.?

The desire of the armed forces for military propulsion power reactors, however, did much to invigorate the Commission's reactor development program. The program, of course, was in such early stages that one could not easily divide it into military and civilian phases. Many technical problems had to be solved which applied to power reactors generally, regardless of their ultimate use. But there was military interest from early days, watching for developments that could be of use in warfare.

Particular impetus came from the Navy. Even before I947, naval circles were planning to make eventual use of power reactors for aircraft and ship or submarine propulsion. ${ }^{8}$ After some earlier consideration, the Navy commenced studies of a reactor and began to acquire data on the problems connected with it. In 1947, to get further data on heat transfer, the Navy negotiated a large research con-

' See Hearings before the Joint Committee on Alomic Energy on Investigation into the United States Atomic Energy Project, 81st Cong., Ist Sess., pt. 19, at 770-77 (1949).

${ }^{7}$ See Atomic Power and Private Enterprise, supra note 5, at 204 .

${ }^{8}$ See id. at 203-06, for the story of early navy interest in nuclear propulsion. 
tract with General Electric, and the AEC agreed to spend a smaller sum on naval reactor studies. After completing studies of the gas-cooled reactor, Oak Ridge began investigating a water-cooled reactor for a submarine at the Navy's suggestion.

During December I947, the whole atomic power program was reviewed by the Navy, and specific recommendations were made to the Secretary of the Navy for working with the AEC on a submarine propulsion plant. The Secretary approved the plan, and proposals for a joint AEC-Navy program were forwarded to the Commission. Following a General Advisory Committee recommendation in favor of such a program, the AEC proceeded with planning. In late 1948, the Commission engaged Westinghouse to construct an experimental propulsion reactor in cooperation with the Argonne Laboratory.

When the AEC came into being, there was also a program for study of nuclear energy for the propulsion of aircraft, the NEPA project. ${ }^{9}$ This study program, which was under neither the MED nor the AEC, was a combined operation of ten aviation companies and the National Advisory Committee on Aeronautics, working with the Fairchild Engine and Airplane Corporation, prime contractor under the Army Air Forces. The project received assistance from the AEC at Oak Ridge, and later carried out certain materials tests at the Commission's Idaho reactor testing station.

The year I949 saw a considerable firming up of the reactor development program, in part due to this military interest. The Commission formalized its several projects into a combined military-civilian program. Its first step was the creation, in late I948, of a new Reactor Development Division, partly on the recommendations of the Industrial Advisory Committee. ${ }^{10}$ Early in I949, the Commission activated the division by the appointment of Dr. Lawrence R. Hafstad as its director. ${ }^{11}$ Soon afterward came the announcement of a new attack on the problems of reactor development, built around four types of military and civilian reactors: the navy thermal reactor for submarine propulsion, a fast breeder reactor, an intermediate breeder reactor, and a materials-testing reactor. ${ }^{12}$ Commissioner Bacher, who revealed the new program, said also that attention was being given to other possible reactors, including aircraft propulsion plants and natural uranium and homogeneous power reactors.

However, the civilian power reactors were not projected primarily to develop power, but to develop the breeding process. This was felt to be important as a possible means of increasing the supply of fissionable materials for military uses. But even the breeder program was too long-range and speculative to withstand the intensification of the international atomic arms race following the first Soviet atomic explosion

\footnotetext{
${ }^{\theta}$ See $i d$. at $178-79$.

${ }^{10}$ See Atomic Energy Commission Names Carleton Shugg Deputy General Manager, Realines Duties of Headquarters Staff Divisions, AEC Release No. 122, Aug. 5, 1948.

${ }^{11}$ See United States AEC Names Dr. Lawrence R. Hafstad Director of Reactor Development Division, AEC Release No. 152, Jan. 16 , 1949.

${ }^{19}$ See Atomic Power and Private Enterprise, supra note 5, at 252-54.
} 
in September 1949. This event led to even more stress on the military side of reactor development and some slackening of work on the program for breeder power plants. Thus, in April I950, the intermediate power breeder being developed by the General Electric Company at Knolls was cancelled. And, faced with a manpower shortage occasioned by the expansion in production at Hanford, which it operated, and the speed-up required on the military projects, General Electric was further compelled to curtail plans it had begun for a closely related intermediate reactor for naval propulsion. ${ }^{13}$

Thus, while the military uses of nuclear power invigorated reactor development, they also held activity away from civilian power projects. Later years saw continued emphasis on atomic military strength, both in expanded production and weapons programs and in the military reactor program. The latter, however, helped in solving technological problems of peacetime power reactors. This was particularly true of the submarine thermal reactor, a pressurized water type, which was closely related to the needs of civilian central-station power plants. The close relationship is shown by the fact that the first large-scale AEC power plant and two of the first industrial proposals are of this general type, as will be seen later.

Throughout the entire period of the early reactor program, the Commission made and executed atomic power policy behind the same barricade of secrecy that hid its weapons programs from the eyes of potential enemies. A few outside groups, it is true, did have access to the restricted realm of the atom, and these had an influence on the program. At first, the General Advisory Committee was extremely important in almost all phases of the AEC's activity. Beginning in I949, under the energetic leadership of Senator Brien McMahon, the Joint Committee on Atomic Energy began to come into its own as a close participant in atomic policy formulation. The Industrial Advisory Committee had access through 1948 to the Commission's programs and made a number of helpful suggestions for improvement. And, of course, the AEC's few contractors had knowledge of the programs and a certain amount of influence. Even taken together, however, these groups made up an extremely small control group. It was still true that the Commission pursued its programs in relative isolation, and there was little outside control, participation, or criticism.

In I95I, however, the AEC began a trend in atomic power development toward ever greater knowledge and assumption of responsibility by private industry. Its new program of industrial participation marked the beginning of the end of the Commission's comparatively exclusive role in atomic power development.

\section{INDUSTRIAL Study Groups}

It was the needs of the military, so prominent in the early years, that gave rise to the Commission's industrial participation program, begun in 1951. This program grew out of a proposal by Dr. Charles A. Thomas, President of Monsanto Chemical

${ }^{13}$ See $i d$. at 276 . 
Company. Dr. Thomas wrote to the AEC on June 20, x950, and suggested a plan whereby ". . . American industry would design, construct, and operate one or more atomic power plants with its own capital."14 According to the plan, the Government would own all fissionable materials. The plants were to be dual-purpose, producing plutonium as well as power. All plutonium would belong to the Government, which was to pay a fee for the production of this fissionable material. Such a fee would offset the high power costs and make the venture profitable for industry, it was felt. On the other hand, the Government would get plutonium at costs lower than those at Hanford, and the national security would be enhanced by increased and more widely dispersed plutonium production facilities.

In later discussions, Dr. Thomas suggested that this plan required three stages: a study of the AEC reactor program, development and design work, and construction and operation of the reactor. ${ }^{15}$ In December 1950, Detroit Edison and Dow Chemical proposed an economic design survey of possible power reactors, which also required access to the AEC's information and know-how as a first stage. ${ }^{16}$

These two proposals favorably impressed the Commission. Early in 1951, the AEC announced its willingness to move ahead with the first step in each proposal: a study of the AEC reactor development program by properly qualified and cleared groups from the industrial concerns involved. ${ }^{17}$ In May I95I, the Commission revealed that negotiations were nearly completed with four groups from industry for the commencement of these study programs. ${ }^{18}$ In addition to the two original groups-Monsanto Chemical-Union Electric and Detroit Edison-Dow Chemicaltwo new groups entered the program: Commonwealth Edison-Public Service of Northern Illinois, and Pacific Gas and Electric-Bechtel. The AEC felt that no further proposals could be considered at the time because of the demands these studies would make on AEC technical personnel.

By April $195^{2}$, interim reports from all four study groups had been submitted to the Commission. The groups manifested a ". . . cautious optimism that the difficult technical and cost factors involved will be solved eventually."19 The DowDetroit Edison group was the first to submit a proposal for going on to the next stage, which included additional research and development work by both the companies and the AEC. Others followed, and a second round of studies finally materialized. Five groups of companies participated-the original four and Foster Wheeler-Pioneer Service-Diamond Alkali.

In late 1953 , the program underwent rapid expansion. ${ }^{20}$ By the spring of 1955 ,

14 See $i d$. at 279.

${ }^{15}$ See id. at $297-98$.

${ }^{10}$ See id. at 296-97.

${ }^{17}$ See id. at 297-30r.

${ }^{18}$ See Atomic Energy Commission Will Consider Maximum of Four Industrial Reactor Studies, AEC Release No. 373, May I6, 195 r.

${ }^{10}$ See AEC Accepts Dow-Detroit Edison Proposal for Continuation of Nuclear Power Production Study, AEC Release No. 422, April 22, 1952.

${ }^{30}$ See United States Atomic Energy Commission, Nuclear Power Reactors i-5 (I955). 
nineteen groups had participated, and eighteen were actively engaged under thencurrent study agreements. Some seventy-one companies made up the study groups. By 1955, several had progressed beyond the initial familiarization stage to undertake plant design and component developmental projects, such as fuel-element tests and heat-exchanger work. ${ }^{21}$

The early industrial participation program was important, not because it resulted itself in any marked alteration in the AEC's role in nuclear power development, but because it laid the groundwork for a new commission role in the period to follow. First, it advanced the technology to a substantial degree. By mid-I954, the AEC reported, the members of the study groups had spent almost five million dollars of their own money on developmental projects. ${ }^{22}$ Second, it gave a number of industrial firms and public-power groups knowledge about nuclear power, without which their participation in future stages of development was naturally impossible. As a result of the study programs, according to the Commission, "... probably half of the [nineteen] groups have acquired sufficient know-how to be potential builders or operators of nuclear power plants." ${ }^{\text {23 }}$ In 1955, eight participants were able to bid on the army package-power reactor. And three members of the group, it was announced, had reached the point where they could undertake design and development programs as a start toward assuming the responsibility for technological advance that had previously been solely the Government's. ${ }^{24}$

\section{Evolution of Policy for the "Induction" Phase}

The first round of studies under the industrial participation program brought forth varying recommendations from the participants, but all were optimistic about the possibility of developing low-cost nuclear power. Meanwhile, the AEC itself had taken a step forward; at the end of $195 \mathrm{x}$, it succeeded in producing small amounts of power from its experimental breeder reactor at the Idaho reactor testing station. $^{25}$

The possibilities for future competitive nuclear power generation, then, seemed bright in 1952 . It remained to attack the unsolved materials, design, and engineering problems. This meant partly that the research and testing of the past would have to be continued. It also meant that, before long, there would have to be construction of actual nuclear power plants, uneconomical though they would be. Only in this way, it was felt, could the final stages of development be carried out, to achieve power so cheap that it would compete with power generated by conventional fuels. Thus, by 1952 , atomic power was moving from the earliest stage of basic research and feasibility studies into the second stage of active developmental work, including

${ }^{21}$ Ibid.

${ }^{22}$ See Hearings before the Joint Committee on Atomic Energy on Development, Grotuth, and State of the Atomic Energy Industry, 84th Cong., Ist Sess., pt. I, at I2 (1955).

${ }^{23}$ See $i d$. at $\mathrm{Ir}$.

24 Ibid.

${ }^{25}$ See Experiment in Generating Power Successful, AEC Release No. 407, Dec. 29, 195 r. 
actual construction and subsequent refinement of the first full-scale "model- $T$ " power plants.

The need for construction of actual power plants became more and more apparent as laboratory and small pilot-plant research and development began to reach the limit of its usefulness in advancing toward competitive nuclear power. Dr. Lawrence R. Hafstad, head of the AEC's Reactor Development Division, told the Joint Committee in mid-I953 that a stage of technology had been reached at which a number of different designs looked good. ${ }^{26}$ It was impossible to tell which particular design would be the "winner" merely by making paper studies and analyses, however. Thus, a number of the best designs had to be built and operated, Dr. Hafstad said, in order to continue progressing toward cheap nuclear power. Chairman Dean elaborated on this by describing the four or five years after 1953 as a development period, which would be characterized by the building of reactor prototypes or experimental reactors. ${ }^{27}$ These would be neither large enough nor sufficiently refined technically to produce economical power, athough they would produce rather substantial amounts of high-cost power, as compared with the previous experimental reactors. It is this developmental period that is referred to as the "induction" phase.

This period posed new issues for the AEC. Early research was, naturally, a commission monopoly. Early industrial study agreements had been able, in most cases, to do little more than provide access to industrial firms to observe the AEC's achievements in this field and to consider the possibility and direction of future efforts. By I952, however, a number of industrial firms had developed sufficient know-how to become active in the later stages of development. How much of a role was private industry to have in this later work? Who was to build the experimental plants necessary to make nuclear power competitive?

The history of the Commission prior to this time indicates a basic philosophy, often stated, of allowing as much opportunity as possible for private groups-primarily business organizations and universities-to participate in the operation of the atomic energy project. The Commission of I95I and I952 continued to assert that private organizations must play a maximum role. In a speech delivered on November 29, r951, Commissioner Glennan expressed concern over ". . . the overlong continuation of the present governmentally dominated industrial-governmental relationship for the prosecution of the atomic program. ..."28 He indicated to his audience of engineers some of the ways in which the AEC had attempted to enlarge the amount of industrial participation and urged them to be alert and aggressive in assuming a share of responsibility for atomic development.

At this same time, there were growing signs that industry was eager to assume this

${ }^{30}$ See Hearings before the Joint Committee on Atomic Energy on Atomic Power Development and Private Enterprise, 83d Cong., Ist Sess. 22-23 (1953).

${ }^{27}$ See $i d$. at 24 .

${ }^{38}$ See Atomic Power and Private Enterprise, supra note 5, at 316. 
share of responsibility. During 1952, some eight different plans for building the first large noncompetitive plants were put forth by various groups inside and outside Government. ${ }^{29}$ These proposals included several different patterns of government and private participation. Some persons thought the AEC should build new production reactors (or adapt those then under construction) to produce power as well as plutonium. By this route, the Government would bear the financial burden of developing reactor technology. This "all-Government" approach contrasted with other suggestions, including those of Detroit Edison, whose president, Walker L. Cisler, suggested that cooperative government-industry research should continue to iron out the problems for a time; then, subject to appropriate revisions in the law, private industry would itself finance and build a full-scale power-plutonium reactor. Several additional proposals contained still other possible arrangements for achieving the early stages of construction and operation.

Late in 1952, the Joint Committee on Atomic Energy determined that the time had come to make whatever basic decisions were required, including amendment of the act, if necessary, to dispel the uncertainty surrounding nuclear power and to get forward with the actual work. Therefore, the Joint Committee requested a policy statement from the AEC and scheduled hearings on atomic power development for the spring of $1953^{30}$

The AEC policy statement received National Security Council approval before it was forwarded to the Joint Committee. It began with these basic points:

I) Development of economically competitive nuclear power is increasingly important both to the national economy and to the maintenance of American world leadership, and it must be carried out with all possible speed.

2) The Commission must continue an active program of research and development, but outside participation by qualified and interested groups is necessary to achieve maximum progress.

3) Reasonable incentives are necessary to encourage such outside participation. The Commission recommended several specific changes in the law which it felt would provide for the necessary incentives. ${ }^{31}$

As to the first point, foreign policy and international considerations had made it urgent to get forward as fast as possible in atomic power development. In May 1953, the National Security Council had determined that early development of cheap nuclear power was necessary to maintain our lead in atomic energy, and the Commission came to feel a compelling responsibility to achieve this important national objective. Achievements in atomic power abroad made it seem vitally important that the United States not be outdone in this field by other nations. Hence, the need for taking the shortest possible route with all dispatch.

To reach this important goal, the Commission contemplated a government pro-

\footnotetext{
${ }^{20}$ See id. at $x 9-26$.

${ }^{30}$ See id. at iii-iv.

${ }^{31}$ See Hearings, supra note 26 , at 6-7.
} 
gram combined with increased private participation, stimulated both by revisions in the act (to give industry greater freedom) and by positive assistance from the AEC. In its statement, the Commission specifically ruled out, however, one of the incentives which had been extremely prominent in prior discussions. It was the objective of its policy, the AEC said, to further the development of nuclear plants which would be economically independent of government commitments to purchase weapons-grade plutonium..$^{32}$ Early consideration of industrial participation, it will be recalled, was mostly based on the dual-purpose idea, that private nuclear plants could be financed only by aid of a long-term AEC commitment to buy fissionable materials produced. As the Government's production program increased, the question arose whether the stockpile might not reach a point at which no more weapons were needed. It was seen to be difficult to assure a permanent market for these materials. Emphasis on materials production seemed likely to slow the advance toward power which was economically practical apart from subsidy through the purchase of materials.

In spite of its desire for eventual increased industrial participation, the AEC was convinced that it would have to do the early prototype building itself. At the hearings, Chairman Dean spoke as if several of the promising types of reactors would have to be pushed to the rather large prototype stage by the Government before private industry took over, and almost everyone agreed that at least one large industrial reactor would have to be government-built. ${ }^{33}$

The 1953 policy remained essentially unchanged during the next two years, while the new program for the transitional or "induction" stage crystallized. In I954, the Commission restated its philosophy in basically the same terms. ${ }^{34}$ In early 1955 , the AEC philosophy had changed little, but the Commission assumed there would be more immediate assumption of industrial responsibility. ${ }^{35}$ The program included advanced government research, plus industrial construction and operation (mainly without government assistance) of a number of early large-scale demonstration power plants.

This AEC philosophy is now being put into practice in a program which does, in fact, combine governmental research with the construction of large demonstration reactors, mostly financed by private industry. The year 1955 marked the beginning of the "induction" phase, wherein cooperative government-business activity is moving to build the first full-scale nuclear power plants, the necessary final step to a genuine atomic power industry.

Under the provisions of the new Atomic Energy Act, the Commission is assuming new roles as this phase of nuclear power development proceeds. From the preceding period, the AEC has continued its operating program. As the principal aspect

${ }^{32}$ See $i d$. at 7 .

${ }^{33}$ See id. at $24-25$.

"s See Joint Committee on Atomic Energy, Report of the Subcommittee on Research and Development on the Five-Year Power Reactor Development Program, 83d Cong., 2d Sess. 6-9 (1954).

${ }^{a 5}$ See Joint Committee on Atomic Energy, Current Statement of the Atomic Energy Commission on the Five-Year Reactor Development Program, 84th Cong., 1st Sess. 2-5 (1955). 
of its activities at present, it is taking on a new role of aid and promotion, to achieve the agreed-upon policy of maximum private participation, including private ownership and operation of power reactors. In order that such scope may be given to industrial activity, the Commission must assume a third role, that of regulator of private operations in the interests of health and safety and the defense and security of the nation. This new regulatory role will loom larger as the atomic power industry becomes more firmly established and the other two roles diminish.

\section{The Commission as Operator}

Continuation of the Commission's own major research program did not require amendment of the act. At the close of the 1953 hearings, upon the request of Chairman Cole of the Joint Committee, the AEC began working out a governmental reactor program which contained those features which seemed most likely to advance the art toward competitive nuclear power and most appropriate for the Government, rather than private industry, to carry out. The result was the Commission's present Five-Year Reactor Development Program. ${ }^{36}$

The first element in the five-year program, the construction of a large-scale, pressurized water power plant for civilian use, was announced in October $19533^{37}$ Commissioner Murray, who first revealed this initial project, said the new central-station power plant would produce a minimum of 60,000 kilowatts of electricity.

Building the PWR, as this pressurized water reactor was called, was in keeping with the role the Commission felt it was necessary to play: construction mainly by government funds of at least one large prototype. It must be said, however, that the decision was precipitated by causes other than the advancing technology of the PWR. Another element in the picture was the world situation in 1953. It has been noted that the new Eisenhower administration was beginning to see peacetime atomic energy as an important pawn in world politics and the cold war. The Joint Committee and the AEC also held this view. The announcement, in October 1953, of Russian success in achieving a thermonuclear explosion intensified the feeling that atomic power policy was vitally important. Speaking for the AEC, Commissioner Murray said that an equally noteworthy achievement by the Russians in peacetime applications would be an even greater blow to the position and prestige of the United States among the world's nations than their success with the H-bomb. Mr. Murray expressed a strong conviction that maintenance of our leadership in the peaceful aspects of atomic energy is a goal of vital national importance. ${ }^{38}$

This combination of technical and policy considerations resulted in a decision that the time was at hand for prototype construction to begin. It was permitted by a provision in the fiscal year 1954 budget, inserted partly on the advice of the Joint Committee, which was pushing the Commission to take this step. Advancing technology had led the Commission to request funds to begin construction of experi-

${ }^{38} \mathrm{Ibid}$.

${ }^{37}$ See N.Y. Times, Oct. 23, 1953, p. 14, col. 3 .

${ }^{38}$ Ibid. 
mental reactors in its original fiscal year 1954 budget, the so-called "Truman budget," prepared by the outgoing administration. When the "Eisenhower budget" was prepared, however, the construction funds disappeared. Partly upon the urging of Chairman Cole of the Joint Committee, the House Appropriations Committee inserted language in the money bill recommending that not to exceed seven million dollars be spent to begin such construction. The need for international leadership in nuclear power resulted in the decision to build immediately a large-scale facility with this authorization, and it was on this understanding that the House Subcommittee voted the provision. ${ }^{39}$

In February 1954, the AEC revealed the remaining elements of its new five-year reactor development program. ${ }^{40}$ This program was based on five approaches-out of "perhaps 80 or more"-to the problem of attaining competitive power. One was the large-scale PWR. The others were to be four small experimental reactors employing as many different principles of design: a boiling water reactor, a sodiumgraphite reactor, a fast breeder reactor, and a homogeneous reactor.

Although this five-year development program was a government program, the Government alone, it was felt, could not bring to bear the same drive toward achieving maximum efficiency and lowest cost. Before going ahead on the PWR, Commissioner Murray said, the AEC had asked again the fundamental question: Would private industry, if permitted by law, do this job itself? By the close of the I953 hearings, however, it had become clear that it was just "not in the cards" for industry to invest the necessary large sums of capital. The AEC did, however, attempt to give private industry the maximum possible role, particularly on the PWR. Commissioner Murray invited offers from industry to invest risk capital in the building of the steam and turbine portions of the plant, as well as in the operation of the entire installation. ${ }^{41}$ This proposal created widespread interest in industry. Nine offers came from as many firms to share in the project. Of these, the one submitted by the Duquesne Light Company of Pittsburgh seemed most favorable to the Government, and was accepted in March $19544^{42}$ Duquesne offered to furnish a site for the project (at Shippingport, Pennsylvania), to build and operate the generating plant, to operate the reactor part of the plant, to assume five million dollars of the cost of research and construction, and to pay the Commission at a specified rate for the steam produced. AEC Chairman Lewis Strauss estimated at the time that this arrangement will reduce the Government's expenditures by thirty million dollars during the period of construction and the first five years of operation.

In the case of the sodium-graphite project, the AEC followed the precedent established with the PWR. The North American Aviation Company, which had

${ }^{\text {s0 }}$ See Statement of Sterling Cole, Joint Committee on Atomic Energy Release, Oct. 22, 1953. See also Hearings before the Subcommittee of the House Committee on Appropriations on Independent Offices Appropriations for 1955, 83d Cong., 2d Sess., pt. 3, at 2575 (1954).

10 See Report, stipra note 34 , at 6-14.

${ }^{11}$ See N.Y. Times, Oct. 23, 1953, p. 14, col. 3 .

${ }^{2}$ See AEC and Duquesne Light Co. to Negotiate on Atomic Power Plant, AEC Release No. 526, March I4, 1954. 
worked on the sodium-graphite principle for some time, contracted to participate with the Government in joint development of the reactor. ${ }^{43}$ North American agreed to assume two and a half million of the ten million dollar project costs and to furnish a reactor site.

\section{The Commission as Promoter}

A. The Statutory Framework

Without amendment of the act, the AEC could hardly have achieved its second goal: primary industrial initiative in constructing additional large-scale demonstration reactors. Such amendment became a reality in August 1954, with the passage of a new Atomic Energy Act.

This greatly revised basic statute offered incentives to increased participation by industry in several ways. Most important, it permitted private ownership of reactors and private use of fissionable material (now called special nuclear material) under a system of licensing and continuing regulation. ${ }^{44}$ It allowed patenting of inventions previously prohibited. ${ }^{45}$ It authorized greater freedom in making available classified technical information to industry. ${ }^{48}$ Finally, as will be seen, it permitted the Commission to offer additional incentive to private participation by granting various types of assistance during the developmental period.

The AEC did not, however, receive much guidance from the act on how to carry out this promotional role; consequently, it has a wide range of discretion. The first question is whether the AEC should offer assistance at all. Subsidy will probably not be a permanent feature in this area, because nuclear power is potentially cheaper than power from ordinary fuel sources. Government aid will not, then, be an indefinite support of a higher level of service than would otherwise occur. Once nuclear power is competitive, if not sooner, industry may be expected to invade the field with enthusiasm. How long aid will be necessary-and whether it will be necessary at all-is for the AEC to decide.

If the Commission decides promotion is necessary, it must resolve the issue of how to carry out this promotion. Several possible routes are provided in the act.

First, the AEC can offer assistance through its discretion in pricing. Since the Government owns all special nuclear material, it was decided that compensation should be given to private reactor owners who produce such material in their facilities. Whoever lawfully produces special nuclear material "shall be paid a fair price." T7 The act specifies the considerations which are to enter into the Commission's determination of a "fair" price. The Commission, says the act, ${ }^{48}$

\footnotetext{
${ }^{43}$ See AEC and North American Aviation Will Share Cost of Sodium-Graphite Reactor Experiment, AEC Release No. 550, July I3, 1954.

44 $\$ \$ 41,53,68$ STAT. 928, 930, 42 U.S.C.A. $\$ \$ 2061,2073$ (Supp. 1954); cf. note 4 stlpra.

${ }^{5} \S_{152}, 68$ STAT. 944, 42 U.S.C.A. $\$ 2182$ (Supp. I954); cf. Atomic Energy Act of 1946, $\$ 11,60$ STAT. 768, 42 U.S.C. \$I8II (1946).

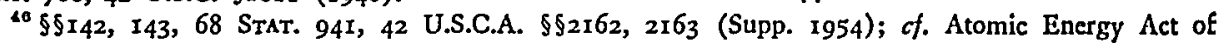
I946, §Io, 60 STAT. 766, 42 U.S.C. \$1810 (I946).

${ }^{17} \$ 52,68$ STAT. 929, 42 U.S.C.A. \$2072 (Supp. 1954).

${ }^{4} \$ 56,68$ STAT. 931, 42 U.S.C.A. $\$ 2076$ (Supp. I954).
} 
... shall take into consideration the value of the special nuclear material for its intended use by the United States and may give such weight to the actual cost of producing that material as the Commission finds to be equitable.

As the Joint Committee report explained, this means that the price is to be based "primarily" on the value to the Government of the intended use, and "only secondarily" on the actual production cost. ${ }^{49}$

This leaves a great deal within the discretion of the Commission. How does one determine the value of an atomic weapon, if it is decided that privately produced materials should be put to this use? Even if the question of value can be solved, do the words "primarily" and "secondarily" have any concrete meaning as used in the Committee report? The act itself is even more vague, stating only that the AEC shall "take into consideration" the one factor, and give such weight to the other as it deems to be "equitable." Even with the committee report, the Commission is hardly given any very specific guidance in setting these prices. Since the price schedules announced early in 1955 remain classified at the time of this writing, it is impossble to observe the manner in which the AEC worked them out.

The Commission also has wide discretion in setting prices for the use of special nuclear material and source material and for other materials and industrial services supplied by the Government. Special nuclear material and source materials may be distributed for use in research and development either without a charge or at a "reasonable charge." 50 The Commission must determine, in writing, criteria to judge whether or not a charge should be made. With special nuclear material, if a reasonable charge is found to be in order, the AEC still has room to set the prices at various levels. One factor to be considered is the cost of material to the AEC, but the use to be made of the material may also be considered, the extent to which that use will "advance the development of the peaceful uses of atomic energy," and the energy value of the material in the use to which it will be put. This allows wide individual adjustments. With source material, there is less opportunity for individual variation, but the AEC still is free to furnish the material without any charge at all, for private research and development.

As to other materials (e.g., heavy water) and industrial services (e.g., fuel-element fabrication and chemical processing), the Commission must set nondiscriminatory prices which provide "reasonable" compensation for the Government and which do not discourage the development of independent sources of supply..$^{51}$ However, under the provision of section $3{ }^{I},{ }^{52}$ permitting the AEC to make research and development contracts and other arrangements, it seems likely that the Commission can provide materials and services without any charge at all, although this problem

${ }^{4}$ See H. R. Rep. No. $218 \mathrm{I}$, JoInt Committee on Atomic Energy, Report to Accompany H.R. 9757. Amending the Atomic Energy Act of 1946, 83d Cong., 2d Sess. 16 (1954). 1954).

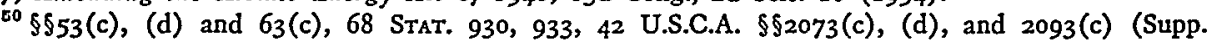

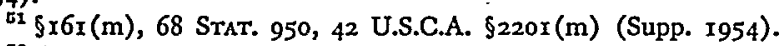

52 68 StAT. 927, 42 U.S.C.A. \$205I (Supp. I954). 
of statutory interpretation has not yet been settled. In any case, the requirement of "reasonable" compensation for the Government is not a strict one and gives the AEC discretion to set prices which substantially aid the private firms involved.

In regard to "burn-up" or loss of special nuclear materials, the AEC is of the opinion that it has discretion under the act to decide whether to charge or not in connection with research and development projects. Section $53(d)(5)$ requires a charge under commercial licenses, but says nothing about section ro4 licenses. ${ }^{53}$ This the Commission interpreted to mean that "we are not required under section 104 to charge for burn-up, but we are not prohibited from doing so." 54

Representatives Holifield and Price of the Joint Committee have pointed out and deplored the additional subsidy possibilities provided by these pricing provisions, over and above the built-in subsidy afforded by retaining government ownership of special nuclear materials and requiring that private producers be compensated.55 Regarding the AEC's power to make a "reasonable charge" for use of materials and to pay a "fair price" for materials produced, they have stated:"6B

But the vague generalities set up in lieu of standards to guide the Commission in determining both these critical figures leaves a degree of discretion in the administrative body that would enable it to pay considerably more for the production than it charged for the original supply of special nuclear material, thus affording private utilities, let us say, subsidies of undetermined magnitude for their participation in the development of nuclear power. Such subsidies resulting from dual transactions might well escape the public eye.

Second, the AEC can assist private endeavor in nuclear power research and development by "arrangements (including contracts, agreements, and loans) for the conduct of research and development activities relating to" a number of specified areas of atomic theory, production, and utilization. ${ }^{57}$ The language of section 169 appears to permit this form of aid in connection with private nuclear power plants under noncommercial section 104 licenses. $^{68}$ As will be seen, this interpretation of the statutory language gave rise to a dispute, the outcome of which is not yet entirely clear.

\section{B. A Concrete Program for Increased Industrial Participation}

With a framework for augmented industrial participation established by the new statute, the Commission moved to take advantage of its potentialities. In January 1955, the classified price schedules were made available. A few days later, Chairman Strauss revealed the new AEC Power Demonstration Reactor Program,

\footnotetext{
${ }^{53} 68$ STAT. 930, 42 U.S.C.A. $\$ 2073$ (d) (5) (Supp. 1954).

${ }^{54}$ See Hearings, supra note 22 , pt. $x$, at 180 .

55 $\$ \$ 52,56,68$ STAT. 929, 93I, 42 U.S.C.A. $\$ \$ 2072,2076$ (Supp. 1954).

${ }^{60} \mathrm{H}$. R. REP. No. $218 \mathrm{I}$, op. cit. supra note 49 , at $13 \mathrm{I}$.

${ }^{67}$ \$31, 68 STAT. 927, 42 U.S.C.A. \$205I (Supp. 1954).

${ }^{88} 68$ STAT. 952, 42 U.S.C.A. \$2209 (Supp. I954).
} 
providing for private development, construction, and operation of large-scale power demonstration reactors, with some financial assistance from the AEC. ${ }^{59}$

The underlying philosophy of this new proposal represented, as noted, a slight advance over the original I953 views. Although the Commission was to continue to push forward with its own experimental and research program, it appeared that further large prototype construction should be turned over mainly to industry. Without further large-scale construction by the Government, the AEC hoped that principal financial and technical responsibility would be accepted by industry in order to achieve economic nuclear power at the earliest possible date. However, the Commission was still convinced that governmental assistance was necessary.

While Congress wrote the new act, the AEC was already working out detailed plans to bring industry into atomic power to an unprecedented degree. The Commission's thinking was revealed in July 1954 by Dr. Hafstad. ${ }^{60} \mathrm{He}$ suggested that the incentives for industry to invest in large but uneconomical developmental reactors might be provided under a cooperative arrangement which he called a "reactor-ofthe-year" program. Under this plan, utilities would substitute a few full-scale atomic reactors for conventional plants in the course of normal expansion. These would unquestionably cost more than conventional plants. The utilities would offer a sum more or less equal to the cost of a comparable, conventional plant at the same location, and the AEC, as part of its research and development expense, would make up the difference. If several such proposals could be developed each year, the one of minimum cost to the Government for the greatest technological advance would be accepted as the "reactor of the year." In addition, the Government would purchase by-product plutonium at a fair price.

Although the new act seemed to preclude the use of commission funds to aid the construction of private nuclear power plants, the Commission remained convinced that some federal aid was necessary. General Manager Nichols explained to the Joint Committee that, "... in our talks to various companies ... none of them felt that the state of the art was yet ready where they could completely finance a research and development reactor of any reasonable size." ${ }^{\prime \prime 1}$

Some members of the Joint Committee questioned this conclusion. Senator Anderson seemed unconvinced that it was wise to make an immediate offer of subsidy. "Why not try them first?" he suggested. "Then if nobody comes in and offers to put up his own money, then say, all right ... we will go the subsidy route. I do not believe you ought to try that first." ${ }^{\text {"2 }}$

What sort of assistance did the Commission determine to be appropriate? One

${ }^{50}$ See AEC Announces Demonstration Program Opening Way for Industrial Power Reactor Development, AEC Release No. 589, Jan. 10, 1955.

${ }^{\circ 0}$ See Industrial Atomic Power and Its Relation to Development of Other Natural Resources, an address by Dr. Lawrence R. Hafstad before the Missouri Basin Inter-Agency Committee, AEC Release, July 2r, r954.

'See Hearings, supra note 22, pt. $x$, at 157 .

${ }^{a}$ See id. at 159. 
form of aid it specifically ruled out: the price schedules indicated that it would be AEC policy not to assist private industry by rigging the secret prices charged and prices paid by the Government so as to give subsidies of a size known only by those with access to classified information. In regard to the payments for privately produced special nuclear material, the Commission put in its price schedule "certain incentives for weapon grade material" during the first seven year period but built the pricing structure essentially around the "fuel value" of the materials." Moreover, the Commission decided to charge for fuel-element fabrication and the various chemical processing operations so as to recover full costs, thus placing the full burden of these operations on industry. ${ }^{64}$ Finally, the Commission exercised its prerogative to charge for special nuclear material consumed or lost. ${ }^{6 \pm}$ The act seemed to indicate, it will be recalled, that these last charges might have been waived.

What, then, was the form in which the AEC proposed to make assistance available to private industry? Under its Power Demonstration Reactor Program, announced at the same time as the price schedules, the makers of acceptable proposals for construction of large-scale demonstration power plants might receive one or more of three kinds of assistance: $:^{\text {Be }}$

... waiver of the charge that the licensee would otherwise have to pay for the use of special nuclear material or source material furnished by the AEC; performance in AEC laboratories and test facilities without charge to licensees of certain mutually agreed upon research and development work; and financial assistance under appropriate research and development contracts.

The first group of proposals to the AEC under the Power Demonstration Reactor Program was received by April I, I955, the deadline set by the Commission. (Assuming favorable and effective responses were made, Chairman Strauss had said, the $A E C$ would establish subsequent dates for receiving additional proposals.) The initial proposals came from Yankee Atomic Electric in Massachusetts, Commonwealth Edison of Chicago and associates, Detroit Edison and associates, and the Consumers Public Power District in Nebraska. ${ }^{67}$ The four proposals included four of the five types of reactors stressed by the Commission in its five-year development program-all except the homogeneous reactor. These projected facilities made up a total of almost 450,000 kilowatts of generating capacity.

Although its proposal was made under the demonstration program, Commonwealth Edison and associates, known as the Nuclear Power Group, did not ask for any of the types of assistance offered by the AEC. One other utility felt that it did not need such aid from the Commission. New York's Consolidated Edison Company applied for a straight license, at about this same time, to build a full-scale

${ }^{63}$ See $i d$. at $75-76$.

ol Ibid.

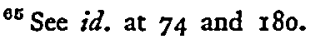

${ }^{68}$ See Release, supra note 59.

'T See Four Proposals Made to AEC Under Power Demonstration Reactor Program, AEC Release No. 620, April 7, 1955. 
nuclear plant at a site on the Hudson River near Peekskill, New York. ${ }^{68}$ The power from this modified version of the Nautilus's pressurized-water reactor was calculated to serve the rapidly increasing power needs of Westchester County, New York. Capacity of the plant was projected at nearly 250,000 kilowatts; I40,000 kilowatts were to come from the nuclear portion and the rest from an oil-fired superheater arrangement.

By the end of August 1955, two additional proposals had been made. One was a project of the Pennsylvania Power and Light Company for a large-scale homogeneous reactor and power plant with a capacity of I50,000 kilowatts, to be located in eastern Pennsylvania. ${ }^{69}$ This meant that all five of the most promising types had been proposed for large-scale private construction. The other plan came from the Rural Cooperative Power Association of Elk River, Minnesota, which suggested construction of a relatively small 22,000 kilowatt plant. $^{\mathbf{7 0}}$

Thus, by the early fall of 1955 , the induction phase of nuclear power development appeared to be under way. It is true that in August, the AEC did reject two of the original demonstration proposals: those of Yankee Atomic Electric and the Consumers Public Power District. But it approved the other two-those of the Commonwealth Edison and Detroit Edison groups- as forming a satisfactory basis for negotiation, and in so doing, paved the way for the first large-scale, privately owned atomic power reactors. ${ }^{71}$

\section{The Commission as Regulator}

The third function of the Atomic Energy Commission during the present transitional, or "induction," stage of atomic power development is regulation. In carrying on this activity, the Commission's transitional role merges with that of the later period of full-fledged atomic industry, when research and development are chiefly to be left to industry, when no promotion will be necessary to induce private firms to engage in what will have become a competitive source of power, and when the Commission will confine its activity in this field mostly to licensing and continuing supervision-that is, to regulatory functions similar to those exercised by the several existing so-called independent regulatory commissions of the federal government.

Those who are induced to enter the present "induction" phase of nuclear power

${ }^{68}$ Ibid. See also testimony of Consolidated Edison's president, H.R. Searing, Hearings, supra note 22, pt. 2, at $402-07$.

${ }^{\circ}$ See N.Y. Times, Aug. 16, 1955, p. 7, col. 3.

${ }^{70}$ See id., Aug. 9, 1955, p. 8, col. 2.

${ }^{71}$ See AEC Authorizes Action Toward New Nuclear Power Reactors, AEC Release No. 674, Aug. 8, 1955. Later, the AEC approved a revised version of the Consumers Public Power proposal as a basis for negotiations. See AEC Authorizes Reactor Power Plant Negotiations With Nebraska Public Power Group, AEC Release No. 723, Oct. 27, x955.

In September 1955, the Commission initiated a second phase of the Power Demonstration Reactor Program by calling for new proposals from industry-this time, to build nuclear plants of less than 40,000 kilowatts capacity. The types of assistance offered were similar to those offered for the original proposals, although the Commission stated its willingness to finance and retain title to all or part of a reactor system as an additional means of aid. See AEC Invites Proposals for Small-Scale Experimental Nuclear Power Plants, AEC Release No. 695, Sept. 21, I955. 
development by the Commission's promotional program (or simply by the hope of getting a head start which will provide bigger ultimate profits) must operate under a strict control scheme established by the 1954 act. First, these firms must submit to the licensing provisions of the act. The primary license requirements are three in number: one who builds or owns a reactor must have a license; one who acquires, processes, or uses nuclear fuel-source material or special nuclear material-must have a license; and one who operates a nuclear reactor must have a license. ${ }^{72}$ This system gives the Commission the opportunity to review in advance all proposed activities and decide whether and under what conditions they should be carried out. Second, private participants must submit to a system of subsequent control, which includes broad inspection and supervision, and the right, under certain circumstances, to suspend or revoke licenses, to order the operation of licensed facilities, or to recapture special nuclear material. ${ }^{73}$

The statute provides for two types of facility licenses, under sections I03 and ro4. ${ }^{74}$ The former are called commercial licenses; the latter, for medical therapy and research and development, may be called noncommercial. No commercial licenses may be issued until the AEC has made a finding in writing that some type of "utilization or production facility has been sufficiently developed to be of practical value for industrial or commercial purposes."75 In regard to the licensing of noncommercial reactors under section ro4-the only kind of facilities which will be built for some years-the Commission's discretion to grant or withhold a license is complete. The section is permissive; it simply authorizes the AEC to issue licenses for certain kinds of reactors under certain conditions.

The way in which the AEC controls development under section I04 may be gauged by extrapolation from the criteria used in the demonstration program. The Commission stated five criteria which would guide its consideration of whether to accept or reject the various proposals that might be made. Decisions were to be made on the basis of $\mathrm{I}$ ) the probable contribution of the proposal toward achieving competitive nuclear power; 2) the cost to the AEC; 3) the financial risk to be assumed by the maker of the proposal; 4) the competence and responsibility of the maker; and 5) the assurance given against abandonment of the project. ${ }^{70}$ It is clear that the AEC intends to make sure that it has ample discretion in arranging for industrial participation. Action has already been taken on the original four proposals; the AEC, however, has given no indication (at the time of this writing) as to which of these criteria resulted in the approval of two proposals and the original rejection of two others.

These, then, are some of the more important aspects of the regulatory scheme

72 §or, 68 Stat. 936, 42 U.S.C.A. \$2131 (Supp. 1954). (1955).

${ }^{73}$ See Herbert S. Marks and George F. Trowbridge, Framework for Atomic Industry iog-19

74 68 StAT. 936, 937, 42 U.S.C.A. $\$ \$ 2133,2134$ (Supp. 1954).

${ }^{75} \S 102,68$ STAT. 936, 42 U.S.C.A. \$2132 (Supp. 1954).

${ }^{76}$ See Release, supra note 59. 
provided by the act. The Commission began to lay the groundwork for its regulatory activities soon after the passage of the Atomic Energy Act of 1954. It first issued two interim orders, one of which continued in effect, for the time being, all the then-existing regulations. ${ }^{77}$ The Commission then undertook the extensive job of drawing up a new body of licensing regulations as required by the new legislation. By early 1955 , the staff work had progressed to the point of submitting some of the draft regulations to the Commission for study. Over the next few months, these draft regulations in the various fields were published so as to make it possible for interested parties to inspect them and make any suggestions that seemed desirable before they became effective. ${ }^{78}$

For administrative purposes, the Commission, in 1955, established a new Division of Licensing, to be responsible for the preparation and administration of AEC regulations dealing with licensing of private atomic energy activities. ${ }^{79}$ Within a short time, however, this was superseded by a Division of Civilian Application. ${ }^{80}$ Its responsibilities include developing and issuing regulations and price schedules, licensing, handling requests for access to restricted data, authorizing distribution of source, special nuclear, by-product, and other materials, and authorizing production of special nuclear material outside the United States.

For purposes of inspection and supervision of licensed activities, the I954 act established a statutory Inspection Division. ${ }^{81}$ The AEC opposed this provision; the function is important, said the Commission, but it is a tool of management and should be flexible to allow administrators to adapt it to their particular needs. ${ }^{82}$ However, Congress went ahead and inserted the provision in the law. Consequently, the Commission set up such a division, with the function of gathering information to show whether contractors, licensees, and officers and employees of the AEC are complying with the act's provisions and commission rules and regulations.

\section{The Commrssion's Multiple Role}

Three principal functions, then, make up the present multiple role of the AEC. This role has become increasingly complex as its newer aspects of promotion and regulation of private activities have come more into prominence. However, these commission functions are closely bound together during this period and require the utmost coordination. Both aspects of the present drive to develop civilian nuclear power-the five-year development program (operating) and the demonstration pro-

${ }^{77}$ See Hearings, supra note 22 , pt. $x$, at 56.

${ }^{78}$ See $i d$. at 57-58. See also remarks of Charles G. Manly, of the AEC's Division of Civilian Application, presented before a Committee of the Machinery and Allied Products Institute, AEC Release, July 27, 1955.

${ }^{70}$ See Division of Licensing Established, Harold L. Price Named Its Director, AEC Release No. 615, March 30, 1955.

${ }^{80}$ See AEC Establishes Division of Civilian Application, Harold L. Price Named Director, AEC Release No. 656, June 29, 1955.

${ }^{81} \$ 25$ (c), 68 StAT. 925, 42 U.S.C.A. $\$ 2035$ (c) (Supp. 1954). See also Hearings, supra note 22, pt. $I$, at 221-22.

${ }^{82}$ See Hearings before the Joint Committee on Atomic Energy on S. 3323 and H.R. 8862, to Amend the Atomic Energy Act of 1946, 83d Cong., 2d Sess., pt. 2, at 605-06 (1954). 
gram (promotional and regulatory)-are so closely related that they seem almost to merge. The tie-up between the two is indicated by two items in the AEC budget request for fiscal year 1956 . In the operating expenses estimates, over and above the amounts for specific five-year development program items, the Commission asked for fifty million dollars for what it called the Power Reactor Acceleration Program. The national interest requires, said the Commission, that the 1954 plans for developing nuclear power be accelerated. Therefore, it was proposed to spend fifty million dollars to expand the "engineering development" on nuclear power reactors and to advance the time when nuclear power will become economically competitive. Of this sum, costs up to ten million dollars were to be incurred in fiscal year 1956 , the rest to be obligated but unpaid. ${ }^{83}$ Later, in the plant and equipment budget, the AEC asked for an additional twenty-five million dollars for 1956 , making a total of seventy-five million dollars for this acceleration program. ${ }^{84}$

Before the Appropriations Committees, commission spokesmen were vague as to just how this money would be used. It developed that the money would not be limited to assisting industrial firms which were carrying out projects under the demonstration reactor program. According to the justifications, the plant and equipment sum was to be available for commission construction of reactors in which industry showed no interest, for construction of government facilities to carry out work required by "both the AEC and private power reactor program," for construction of testing or processing facilities needed because of advances in reactor or reactor component design, and for joint industry-government projects where the AEC might build and own a portion of the plant. The operating expenses item was also to be utilized both in connection with the proposals from industry and in order to accelerate the Commission's own projects. ${ }^{85}$

The AEC, throughout, asked for a maximum of flexibility on this item. Before the Joint Committee approved authorization of the twenty-five million dollars in capital funds, Representative Durham wanted the agency to suggest some formula specifying that a given percentage of cost would be allocated to industry and the rest to Government under the joint demonstration program phase. General Manager Fields indicated that this was impossible, that the AEC did not know just what sort of proposals would later be received, and that the percentage of contribution by each participant might vary widely. It might be necessary for the Government to support some promising types nearly roo per cent, and others only to per cent. $^{86}$

"What you are essentially asking for," said Representative Holifield, ". . . is a

${ }^{83}$ See Hearings before the Subcommittee of the House Committee on Appropriations on H.R. 6766, Public Works Appropriations, 1956, 84th Cong., Ist Sess. 391 (1955).

${ }^{84}$ See Hearings before the Subcommittees of the House Committee on Appropriations on the Supplemental Appropriation Bill, 1956, 84th Cong., Ist Sess. 985 (1955).

${ }^{85} I d$. at $985-86$.

${ }^{86}$ See Hearings before the Subcommittee of the Joint Committee on Atomic Energy on Authorizing Legislation, 84th Cong., ist Sess. 13-14 (1955). 
floating fund of twenty-five million dollars which, as the different reactor programs are developed, you may assign on the judgment of the Commission . . . as you feel will be necessary for each one of these reactor programs."87 Commissioner Libby agreed that this was true..$^{88}$

It was not unrealistic to assume that some of the more promising types of reactors might not be proposed by industry. The initial offers made by industry under the Power Demonstration Reactor Program did not include the homogeneous type, considered by the AEC to be perhaps the most promising of all in the long run. The Commission anticipated such a development and discussed it with the Joint Committee prior to receipt of the April I proposals. Representative Holifield strongly urged that the Government cannot just let this program lag. "If we do not get the proper kind of responses to the different types of reactors that seem feasible," he went on, ". . . the Government should go ahead with experimental work. . . . We cannot afford to be outdistanced in this field by foreign powers."89

Although Mr. Holifield was most insistent, the AEC and the Joint Committee seemed generally to share his feeling. Later, when the first proposals were all in, Commissioner Libby stated his surprise and disappointment that no one planned to build a large homogeneous reactor, and suggested that he would strongly favor governmental development and construction if no one took the initiative on this reactor type at the next submission of proposals. ${ }^{90}$ This did not become necessary in the case of this particular type because of the later proposal by the Pennsylvania Power and Light Company. But it was by no means assured that the five reactor types stressed under both the five-year program and the demonstration program would ultimately prove to be the most fruitful designs. The AEC at this time (midI955) was working ahead on several additional reactor types which might, it seemed, turn out to be even more promising than the original five. In this case, the AEC will, doubtless, again stand ready to assume the initiative in large-scale construction if industry should fail to do so.

The over-all goal of maximum progress toward economic nuclear power, then, binds together the present governmental and private programs. It conditions the AEC's own efforts and the nature of the promotion to be carried on. The Commission must stimulate industrial participation not only for its own sake, but as a means of achieving competitive power most swiftly, as required by the need to keep in the forefront of world atomic energy development. In this joint operation, coordination and harmonization are necessary. This must be the task of the AEC.

\section{Transition to the Regulatory Phase}

The present three-part role of the AEC in civilian atomic power is a transitory one. Later, the Commission's operating and promotional roles in the field will

${ }^{87}$ Id. at 13.

8 Ibid.

${ }^{80}$ See Hearings, supra note 22, pt. 2, at 423.

${ }^{\circ 0}$ See Hearings, stupra note 86 , at 55 . 
presumably diminish as the atomic industry gets under way in earnest. Since the atom offers a potentially cheap source of power, there should be no need for permanent subsidization to maintain a high level of progress in constructing and perfecting nuclear plants. The Commission should be able to allow industry to handle most of the development work; thus, the principal duties that will fall to the AEC will be those of a regulatory nature.

This future period of full-scale atomic industry will involve section ro3 licenses for construction and ownership by private firms of atomic power reactors. At first reading, the law seems to draw such a distinction between these and section ro4 developmental licenses that the future period of regulation appears likely to be characterized by a lesser degree of control by the AEC and more freedom for private activity. However, when the language of the act is closely examined, one sees that it allows the Commission substantially as much discretion to grant or refuse licenses, and to control those granted, as under section $104{ }^{01}$

There has been some criticism of the 1954 act because of the strictness of the regulatory scheme set forth therein. It is an unusual field, and the requirements of security and safety are unusually great. Furthermore, there is, as yet, little experience with which to give meaning to some of the terminology and concepts used by Congress in setting forth and defining the procedures and policies to be followed by the AEC. If it seems that the agency's discretion is extremely broad, it is perhaps the result of the fact that experience in atomic power is so meager that it is now impossible to legislate in meaningful terms. Perhaps the several years of experience under section I04 which will precede the granting of any section ro3 commercial licenses will be such as to give meaning to the standards and policies Congress incorporated in the act. If not, it may be that the law will have to be amended to clarify and specify in certain areas in order to leave the agency somewhat less free to take whatever course it feels is appropriate.

Whatever modifications may be made in the statutory framework supporting the regulatory functions of the Commission, the problem will remain of combining in one agency a substantial load of regulatory duties and an equally substantial operating program in the fields of production, weapons, research, and reactors for military propulsion. It is essentially the same organizational problem as that posed by the threefold combination of the present developmental period. The arguments for retaining all functions in one agency may be less compelling in this later stage; the traditional issue of the wisdom of combining regulation with the executive and operating activities will be more pertinent.

Most political scientists argue against such a combination, particularly in agencies headed by a group of commissioners. "The common experience is," said the first Hoover Commission's task force, "that groups are better fitted for judgment and

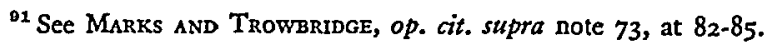


decision than for the execution of large-scale operations."92 Furthermore, the task force continued, most regulatory commissions find that their purely regulatory duties are extremely time-consuming; not only are they not fitted for operating functions, but performance of these weakens their ability to perform their primary functions by taking time that should be devoted to regulatory duties. The task force suggested that operating functions should be placed in the regular departments as far as possible, so that they may be carried out under direct executive supervision and responsibility.

The problem, however, is not an immediate one, for it will arise only when the nuclear power industry becomes a reality. How long is the present transitional or "induction" stage likely to last? Although atomic energy has been one of the areas most productive of wrong predictions and inaccurate guesses about the future, even from the best informed, a few points are clear. One is that the first round of large-scale demonstration power plants will just be starting to operate by $I 960$, assuming that some of them can get under way soon. One cannot help thinking that the 1959 completion date set by Detroit Edison is over-optimistic. Even the PWR will not be completed until r957. In any case, experience with these first plants, and perhaps with subsequent ones which may be begun in the next year or two, cannot be expected to be available before the early I960's. One hesitates to predict the end of the induction stage before I965. The AEC's Reactor Development Division head, W. Kenneth Davis, has said that the induction phase will probably end at about that date, although it may vary two or three years either way. ${ }^{93}$ The end will be largely a psychological point, he has suggested, when confidence in the eventual advantages of nuclear power becomes so great that atomic plants form a large proportion of all new power plants. At this date, the problems will probably still not be solved, and no one will have generated nuclear power that actually is competitive.

It is easy to see that the AEC is not about to be overwhelmed with regulatory duties emanating directly from the generation of nuclear power. For at least a decade, the number of atomic power plants will probably be small. During that time, the AEC may be expected to continue in its operating-promotional-regulatory role, which forms the bridge to the atomic power industry of the future.

\footnotetext{
${ }^{2}$ Commission on Organization of the Executive Branch, Task Force Report on Regulatory Commissions, Appendix N 30 (1949).

${ }^{03}$ Sce Nuclear Power Industry Development, an address by W. Kenneth Davis before the American Power Conference, AEC Release, April I, 1955, p. 7.
} 